\title{
NOTE
}

\section{Effects of CB-154 (2-Br- $\alpha$-Ergocryptine) on Prolactin and Growth Hormone Release in an Acromegalic Patient with Galactorrhea}

\author{
Gaiko UEDA, Yasuko SATO, Masato YAMASAKI, \\ TAKENORI SHIOJI, TOSHIHIRO AONO \\ AND KEIICHI KURACHI \\ Department of Obstetrics and Gynecology, \\ Osaka University Medical School, Dojima, Osaka 553
}

\begin{abstract}
Synopsis
An acromegalic patient with galactorrhea was treated with an ergot alkaloid, 2-Br- $\alpha$-ergocryptine (CB-154). Serum prolactin decreased rapidly to normal level by CB-154 and the complete cessation of galactorrhea was noted. The inhibitory effect of CB-154 on growth hormone $(\mathrm{GH})$ release was also noted, but slight. The mechanism of inhibitory action of CB-154 on both prolactin and $\mathrm{GH}$ secretion was discussed in connection with the experimental model of pituitary tumors, in which both hormones were produced by a single type of tumor cells. The discontinuation of CB-154 treatment was associated with the return of both prolactin and GH levels to the initial high values with resumption of galactorrhea.
\end{abstract}

The ergot alkaloid 2-Br- $\alpha$-ergocryptine (CB-154; Sandoz) is now well known to inhibit specifically the secretion of prolactin in animals (Flückiger and Wagner, 1968; Yanai and Nagasawa, 1970; Billeter and Flückiger, 1971; Flückiger et al., 1972), in human pituitary tissue cultures (Pasteels et al., 1971), and in clinical trials (Lutterbeck et al., 1971; Besser et al., 1972; Varga et al., 1972), but not of growth hormone (GH) (Yanai and Nagasawa, 1970 and 1974; MacLeod and Lehmeyer, 1972).

MacLeod and Lehmyer (1973), however, reported that ergot alkaloids inhibited not only synthesis and secretion of all three hormones (prolactin, $\mathrm{GH}$ and $\mathrm{ACTH}$ ) but also the tumor growth in the experimental pituitary tumor system. In the experimental pituitary tumors, prolactin cells were proved to gain ability to produce $\mathrm{GH}$ as well (Ueda et al., 1973), suggesting the possibility that CB-154 might inhibit even the secretion of

Received for publication January 29, 1975.
$\mathrm{GH}$ as well as prolectin. The multihormonal activities of pituitary tumor cells were also described in the human being (Zimmerman et al., 1974), suggesting that CB-154 might be useful for the treatment of acromegalic patient with galactorrhea.

\section{Case Report}

A 30 year-old gravida 3, para 2 patient had been suffering from acromegalic symptoms (promiment cheek bones, protruding jaw, frontal bossing, broad and spadelike fingers, and increase in the body weight and stature) and hirsutism for several years. She developed persistent galactorrhea after the artificial abortion in January, 1971. Menstruation was irregular at that time and became amenorrheic since January, 1972.

\section{Physical examination}

Acromegaly, galactorrhea, amenorrhea and hirsutism were found in our outpatient clinic 
on February 15, 1973. X-ray examination of the skull revealed an enlargement of the sella turcica more than $110 \mathrm{~mm}^{2}$, suggesting a pituitary tumor.

\section{Laboratory examination.}

No pathology was found in either the urine or the blood with hematologic and chemical analyses, including the function tests for liver and kidneys. Serum levels of testosterone and progesterone were $0.13 \mu \mathrm{g} / \mathrm{d} l$ (normal values, $0.02-0.05 \mu \mathrm{g} / \mathrm{d} l$ ) and $0.4 \mathrm{ng} / \mathrm{m} l$ (normal values, less than $2 \mu \mathrm{g} / \mathrm{d} l$ in the follicular phase and less than $15 \mathrm{ng} / \mathrm{d} l$ in the luteal phase), respectively. To evaluate the function of pituitary-gonadal axis, LH-RH test and premarin test were performed and found to be within normal ranges. The 24-hour urinary excretions of 17-hydroxycorticosteroids and 17 -ketosteroids were measured to be $5.5 \mathrm{mg}$ and $10.2 \mathrm{mg}$, respectively. Rapid ACTH test and metopyrone test also revealed normal function of pituitary-adrenal axis. Thyroid function was considered to be within normal ranges judging from the following data: serum TSH level, $1.3 \mu \mathrm{U} / \mathrm{m} l ; \mathrm{T}_{4} \mathrm{I}, 6.9 \mu \mathrm{g} / \mathrm{d} l$; PBI, $8.0 \mu \mathrm{g} / \mathrm{d} l$; Triosorb test, $22 \%$; BMR,
$+18 \%$; and the normal response of TSH to TRH. The serum levels of GH and prolactin were measured by radioimmunoassay (Kumahara et al., 1970; Onishi et al., 1975). Basal levels of GH of this patient were high, 59.0$72.0 \mathrm{ng} / \mathrm{m} l$, and increased to the peak values $82.8-156.0 \mathrm{ng} / \mathrm{m} l$ by insulin-induced hypoglycaemia. Normal values for adults were $1.4 \pm 2.23 \mathrm{ng} / \mathrm{m} l$ and $37.0 \pm 20.37 \mathrm{ng} / \mathrm{m} l$, respectively (Kumahara et al., 1970). Serum levels of prolactin of the patient were 23.4$32.4 \mathrm{ng} / \mathrm{m} l$ and higher than the control values, $10.6 \pm 3.9 \mathrm{ng} / \mathrm{m} l$ in this laboratory. The peak value of serum prolactin after TRH injection was $78.0 \mathrm{ng} / \mathrm{m} l$ and higher than $23.1 \pm 18.0$ $\mathrm{ng} / \mathrm{m} l$ in controls (Onishi et al., 1975).

\section{Treatment protocol}

Treatment of patient was first begun with 1-dopa for 5 weeks and followed by CB-154 for about 6 mohths. The effectiveness of treatments was evaluated by the fall of serum $\mathrm{GH}$ and prolactin levels and the change of clinical symptoms such as galactorrhea, amenorrhea and so on, as shown in the Figure 1. No side effects were seen by these treatments.

While on 1-dopa treatment, $0.5 \mathrm{~g}$ orally

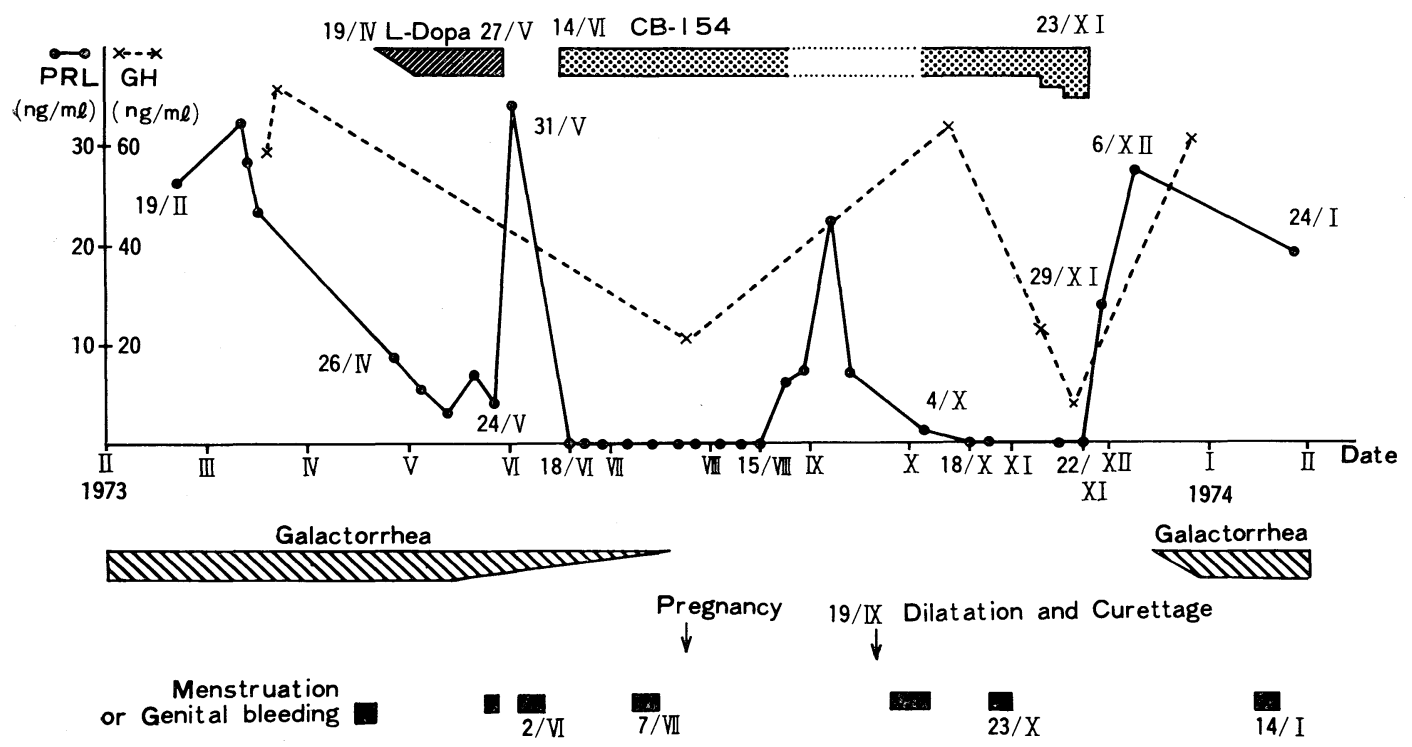

Fig. 1. Treatments, serum levels of prolactin and growth hormone, and clinical symptoms. 
every 6 hours, milk secretion became slight but persisted. Serum level of prolactin fell down to $3.0-8.8 \mathrm{ng} / \mathrm{ml}$ in a week or later, but rose up again to $34.2 \mathrm{ng} / \mathrm{m} l \quad 4$ days after discontinuation of the treatment. Serum GH value was not determined.

Two weeks after discontinuation of 1-dopa treatment, CB-154 was given orally $7.5 \mathrm{mg}$ a day and found effective dramatically. Galactorrhea ceased completely in a few days. Serum level of prolactin was undetectable (less than $0.4 \mathrm{ng} / \mathrm{ml}$ ) when measured at 4 days after the beginning of treatment. Serum prolactin values continued to be undetectable for about 2 months until the patient became pregnant. Pregnancy did not permit the patient to take CB-154 tablet temporarily because of nausea and serum prolactin levels rose up to $6.0-22.6 \mathrm{ng} / \mathrm{m} l$ when measured in 3 days or later. After artificial abortion, the patient was again on CB-154 treatment and serum prolatin values became undetectable. Prolactin levels in the serum, however, rose up again to $14.0-27.6 \mathrm{ng} / \mathrm{ml}$ immediately after discontinuation of CB-154 treatment. Also, galactorrhea reappeared in 3 weeks.

Serum levels of GH which were $59.0-72.3$ $\mathrm{ng} / \mathrm{m} l$ before CB-154 therapy, fell down to $24.6-8.4 \mathrm{ng} / \mathrm{m} l$ during the treatment, but went up to $64.4-61.5 \mathrm{ng} / \mathrm{m} l$ when CB-154 administration was discontinued as shown in the Figure 1. The patient was transferred to Department of Neurosurgery for surgical treatment.

\section{Discussion}

Although the exact mechanisms of lactation are not understood and the serum levels of prolactin do not necessarily parallel with the grade of galactorrhea (Tolis et al., 1974), prolactin is generally considered indispensable for inducing milk secretion (Meities, 1973). Ergot alkaloids are known to inhibit prolactin secretion primarily through the direct action to the pituitary ( $\mathrm{Lu}$ et al., 1971), but also indirectly through the increase of hypothal- amic prolactin inhibiting factor activity (Wuttke et al., 1971). Clinical application of CB-154 has proved effective to suppress puerperal (Del Pozo et al., 1972; Varga et al., 1972; Brun del Re et al., 1973), and nonpuerperal (Lutterbeck et al., 1971; Copinshi et al., 1971/1972; Del Pozo et al., 1972; Varga et al., 1973) lactation.

L-dopa treatment of patients with the Forbes-Albright syndrome was reported to be effective (Turkington, 1972). It inhibited the prolactin secretion and resulted in the complete cessation of galactorrhea. In the present case, 1-dopa caused the decrease of serum prolactin levels but milk secretion persisted.

CB-154 therapy was also successfully applied to the galactorrheic patients bearing pituitary tumors (Lutterbeck et at., 1971; Copinshi et al., 1971/1972). It suppressed the pituitary prolactin secretion and galactorrhea. In a comparative study of CB-154 and 1-dopa on prolactin secretion, CB-154 was more effective than 1-dopa under certain circumstances (Copinshi et al., 1971/1972). Likewise, the effects of CB-154 were prompt and complete in the present case while those of 1-dopa were not.

The pathogenesis of acromegaly with galactorrhea is not yet clearly understood, but might be explained in some cases by the experimental model of pituitary tumors; prolactin producing tumor cells seemed to gain the ability to produce GH and possibly ACTH as well (Ueda et al., 1973).

The possibility that CB-154 may reduce serum GH levels was shown in the present acromegalic patient with lactation, although the sparcity of the data on serum GH was unfortunate. Actually, the decrease of plasma GH level after a single oral dose of CB-154 was reported in acromegalic patients (Liuzzi et al., 1974) during the preparing of the present paper. This mechanism is unclear, but it might be speculated from the data of analogous experimental pituitary tumors that seme cells of the present tumor were able to produce both prolactin and $\mathrm{GH}$ and under 
the inhibitory influences by CB-154 treatment.

The restoration of ovulatory function and fertility by CB-154 treatment in the galactorrheic, amenorrheic patients was occasionally reported (del Pozo and Flückinger, 1973; Varga et al., 1973; Seki and Seki, 1974), but the pituitary tumor patient who became pregnant while on this treatment was not described before. The more detailed endocrinological studies on resumption of ovulatory cycles in the present case will be published later.

\section{Acknowledgements}

The authors are indebted to NIAMDD for prolactin RIA kit, to Sandoz, Ltd. for the gifts of CB-154 and also to staffs of Central Laboratory for Clinical Investigation (Director; Dr. Y. Kumahara) for TSH, GH and a part of prolactin determination.

\section{References}

Besser, G.M., L. Parke, C.R.W. Edwards, I.A. Forsyth and A.S. McNeilly (1972). Br. Med. J. 3, 669.

Billeter, E. and E. Flückiger (1971). Experientia 27, 464.

Brun del Re, R., E. del Pozo, P. de Grandi, H. Friesen, M. Hinselmann and H. Wyss (1973). Obst. Gyn. 41, 884.

Copinshi, G., M.L'Hermite, J.L. Pasteels and C. Robyn (1971/1972). Hormones and Antagonists Gyn Invest, 2, 128.

Del Pozo, E., R. Brun del Re, L. Varga and H. Friesen (1972). J. Clin. Endocr. 35, 768.

Del Pozo, E. and E. Flückiger. Human Prolactin. (edited by J.L. Pasteels and C. Robyn). Excerpta Medica, P. 291 (1973).

Flückiger, E., P.M. Lutterbeck, H.R. Wagner and E. Billeter (1972). Experientia 28, 924.

Flückiger, E. and H.R. Wagner (1968), Ibid 24, 1130.
Kumahara, Y., Y. Okada, K. Miyai and H. Iwatsubo (1970). Acta Endocrinol. 63, 618.

Liuzzi, A., P.G. Chiodini, L. Botalla, G. Cremascoli, E.E. Muller and F. Silvestrini (1974). J. Clin. Endocr. 38, 910.

Lu, K.H., Y. Koch and J. Meites (1971). Endocrinology 89, 229.

Lutterbeck, P.M., J.S. Pryor, L. Varga and R. Wenner (1971). Br. Med. J. 3, 228.

MacLeod, R.M. and J.E. Lehmeyer (1973). Cancer Res. 33, 849.

MacLeod, R.M. and J.E. Lehmeyer (1972). Wolstenholme and Knight Lactogenic hormones, Livingstone, Edinburgh.

Meites, J. Methods in Investigative and Diagnostic Endocrinology, Part II (edited by S.A. Berson and R.S. Yalow).

Onishi, T., K. Miyai, K. Izumi, H. Nakanishi and Y. Kumahara (1975). J. Clin. Endocr. (in press).

Pasteels, J.L., A. Danguy, M. Frénotte and F. Ectors (1971). Ann. Endocrinol. (Paris) $32,188$.

Seki, K. and M. Seki (1974), J. Clin. Endocr. 38, 508.

Tolis, G., M. Somma, J. van Campenhout and H. Friesen (1974). Am. J. Obst. Gyn. 118, 91 .

Turkington, R.W. (1972). J. Clin. Endocr. 34, 306.

Ueda, G., P. Moy and J. Furth (1973), Int. J. Cancer. 12, 100.

Varga, L., P.M. Lutterbeck, J.S. Pryor, R. Wenner and H. Erb (1972). Br. Med. J. 2,743 .

Varga, L., R. Wenner and E. del Pozo (1973). Am. J. Obst. Gyn. 117, 75.

Wuttke, W., E. Cassell and J. Meites (1971). Endocrinology 88, 737.

Yanai, R. and H. Nagasawa (1970). J. Nat. Cancer. Inst. 45, 1105.

Yanai, R. and H. Nagasawa (1974). Hormone Res. 5, 1.

Zimmerman, E.A., R. Defendini and A.G. Frantz (1974). J. Clin. Endocr. 38, 577. 